\title{
Factors associated with Regular Dental Attendance among White-collar Workers
}

Seitaro Suzuki ${ }^{1^{*}}$, Koichi Yoshino ${ }^{1}$, Atsushi Takayanagi ${ }^{1}$, Yoichi Ishizuka ${ }^{1}$, Ryouichi Satou ${ }^{1}$, Yuki Onose ${ }^{1}$, Takako Eguchi ${ }^{1,2}$, Hideyuki Kamijo $^{3}$ and Naoki $^{1}$ Sugihara ${ }^{1}$

${ }^{1}$ Department of Epidemiology and Public Health, Tokyo Dental College, Tokyo, Japan

${ }^{2}$ Tokyo Dental College School of Dental Hygiene, Japan

${ }^{3}$ Department of Social Security for Dentistry, Tokyo Dental College, Tokyo, Japan

"Corresponding author: Seitaro Suzuki, Department of Epidemiology and Public Health, Tokyo Dental College, 2-9-18, Misaki-cho, Chiyoda-ku, Tokyo 101-0061, Japan, Tel: +81 36380 9272; Fax: +8136380 9606; E-mail: suzukiseitarou@tdc.ac.jp

Rec date: Apr 28, 2015; Acc date: May 07, 2016; Pub date: May 16, 2016

Copyright: $\odot 2016$ Suzuki S, et al. This is an open-access article distributed under the terms of the Creative Commons Attribution License, which permits unrestricted use, distribution, and reproduction in any medium, provided the original author and source are credited.

\section{Abstract}

Background: It has been reported that some factors associated with regular dental attendance. Meanwhile, few reports have discussed a relationship between work environment, lifestyle and oral hygiene behaviour.

Aim: To identify factors associated with regular dental attendance among white-collar workers.

Method: This cross-sectional internet-based survey was conducted to identify factors associated with regular dental attendance among white-collar workers. The participants were asked to complete a self-reported questionnaire. A total of 834 daytime-only workers and 109 night-shift workers aged 30 to 69 years were analysed.

Result: Work environment, lifestyle and oral hygiene behaviour were included in the analysis. Multiple logistic regression analysis was performed to identify the relationship between these factors and regular dental attendance. As a result, significant differences were observed with the following parameters after adjusting for possible confounding factors: duration of eating breakfast (adjusted odds ratio [AOR], 1.72; 95\% confidence interval [95\% $\mathrm{Cl}$, 1.285-2.297), brushing before bed time (AOR, 1.72; 95\% Cl, 1.302-2.263), duration of brushing teeth (AOR, $1.56 ; 95 \% \mathrm{Cl}, 1.188-2.046)$, shift work (AOR, 1.55; 95\% Cl, 1.067-2.261)and $\mathrm{My}$ job is worth doing (AOR, 1.50 ; $95 \% \mathrm{Cl}, 1.129-1.993)$.

Conclusion: These results indicate that work environment, lifestyle and oral hygiene behaviour are associated with regular dental attendance. In particular, shift work and work stress was associated with regular dental attendance with regard to work environment. Therefore, health care providers might be able to promote dental attendance by informing workers that the work environment, lifestyle and oral hygiene behaviour might be associated with regular dental attendance.

Keywords: Regular dental check-ups; Work environment; Lifestyle; Internet survey

\section{Introduction and Background}

Regular dental attendance has been reported to be associated with better oral status and oral health-related quality of life [1-5]. Thomson et al. reported that long-term routine dental attendance would be related to better self-reported oral health and less tooth loss and cavities in a prospective cohort study in New Zealand that examined 932 participants from the age of 15 years till the age of 32 years [5]. Therefore, promoting and maintaining regular dental attendance is important to improve oral health.

Although gender, age and income have been reported as associated factors with regular dental attendance [2,4,6-11], few reports have discussed a relationship between work environment, lifestyle and oral hygiene behaviour. Factors such as gender, age and income are difficult to control. However, factors such as work environment, lifestyle and oral hygiene behaviour could be controlled. In addition, it has been reported that health behaviours were associated with job characteristics [12]. Therefore, we selected white-collar workers as a target group to make the job characteristics similar. We expected that these factors would be associated with regular dental attendance. By revealing this relationship, health care providers may promote regular dental attendance to improve oral health among workers. Accordingly, the purpose of our study was to identify factors associated with regular dental attendance among white-collar workers.

\section{Material and Methods}

\section{Participants}

This survey was conducted in Japan from 20 February 2015, to 11 March 2015 via the Internet. The participants were selected from people who registered with an online research company called Macromill (http://www.macromill.com/global/index.html). They were between 30 and 69 years of age and were fulltime or part-time workers. The respondents completed the questionnaire after they had agreed to participate in the survey via a website. Therefore, among the respondents there were teachers, clerks, salespersons or administrators and they were collectively referred to as white-collar workers [13]. Moreover, we excluded the respondents who did not report their 
Page 2 of 5

family income. As a result, 834 daytime-only workers and 109 nightshift workers aged between 30 and 69 years were analysed (a total of 1023 people).

\section{Questionnaire components}

The respondents completed a self-reported questionnaire. We selected gender, age and family income as adjustment factors as these factors have been reported to be associated with regular dental attendance [2,4,6-11]. Moreover, work environment [14,15], lifestyle [16-18] and oral hygiene behaviour $[19,20]$ were included as questionnaire components because these factors have been reported as factors associated with dental diseases or regular dental attendance. As an indicator of measuring work stress, we picked some components in reference to the English version of the Brief Job Stress Questionnaire created by the Japanese Ministry of Health, Labour and Welfare [21].

Table 1 shows a list of questionnaire items. The categories are as follows: Family income; work environment (working hours, shift work, factors associated with work stress; lifestyle (smoking status, frequency of eating breakfast and dinner on weekdays, duration of eating breakfast, frequency of eating out on weekdays, eating snacks between meals); oral hygiene behaviour (frequency of daily brushing, duration of brushing teeth, timing of brushing teeth). Regular dental attendance was elicited by asking 'Do you have regular dental attendance including preventive treatment?' The respondents answered an interval of regular dental attendance if they had regular dental attendance. Then, we categorized the answers as within a year or not.

\begin{tabular}{|c|c|}
\hline Items & Category \\
\hline \multicolumn{2}{|l|}{ Family income } \\
\hline 'How much is your annual family income?' & $\begin{array}{l}<4 \text { million yen or } 4-6 \text { million yen } \\
\text { or } \geq 4 \text { million yen }\end{array}$ \\
\hline \multicolumn{2}{|l|}{ Working hours } \\
\hline ‘How many hours do you work a day?' & $<8 \mathrm{~h}$ or $\geq 8 \mathrm{~h}$ \\
\hline \multicolumn{2}{|l|}{ Shift work } \\
\hline 'Do you work in shifts?' & Yes or no \\
\hline \multicolumn{2}{|l|}{ Factors associated with work stress } \\
\hline 'My job is worth doing' & Yes or no \\
\hline 'I have to pay careful attention’ & Yes or no \\
\hline 'This job suits me well' & Yes or no \\
\hline $\begin{array}{l}\text { 'The atmosphere at my workplace is } \\
\text { friendly' }\end{array}$ & Yes or no \\
\hline 'I feel stressed about my work’ & Yes or no \\
\hline Smoking status & \multirow{2}{*}{$\begin{array}{l}\text { Smokers or ever-smokers and } \\
\text { non-smokers }\end{array}$} \\
\hline ‘Do you smoke?’ & \\
\hline \multicolumn{2}{|l|}{$\begin{array}{l}\text { Frequency of eating breakfast and dinner } \\
\text { on weekdays }\end{array}$} \\
\hline $\begin{array}{l}\text { 'How often do you eat breakfast and dinner } \\
\text { on weekdays?' }\end{array}$ & Every day or not every day \\
\hline Duration of eating breakfast & \\
\hline
\end{tabular}

\begin{tabular}{|l|l|}
\hline $\begin{array}{l}\text { 'How many minutes do you spend your time } \\
\text { on eating breakfast?' }\end{array}$ & $\begin{array}{c}\text { Not eating breakfast and }<5 \\
\text { minutes or } \geq 5 \text { minutes }\end{array}$ \\
\hline Frequency of eating out on weekdays & \\
\hline 'How often do you eat out on weekdays?' & $\begin{array}{c}\text { More than } 1 \text { time per week or } \\
\text { never }\end{array}$ \\
\hline Eating snacks between meals & \\
\hline 'Do you eat snacks between meals?' & Yes or no \\
\hline Frequency of daily brushing & $<2$ or $\geq 2$ \\
\hline 'How often do you brush your teeth a day?' & \\
\hline Duration of brushing teeth & $<3$ minutes or $\geq 3$ minutes \\
\hline 'How many minutes do you brush your \\
teeth?' \\
\hline \begin{tabular}{l} 
Timing of brushing teeth \\
including preventive treatment?' \\
'Weating breakfast, after eating lunch, before \\
\hline Regular dental attendance
\end{tabular} & Yes or no \\
\hline Within a year or not \\
\hline
\end{tabular}

Table 1: List of self-reported questionnaire components

\section{Statistical Analysis}

Initially, a chi-squared test (or the Fisher exact test for cases with fewer than five cells in the contingency table) was performed to reveal the distribution of the respondents for determining regular dental attendance. Subsequently, multiple logistic regression analysis was performed using regular dental attendance as the dependent variable and adjustment factors (gender, age and family income); work environment, lifestyle and oral hygiene behaviour were used as the independent variables. The multiple logistic regression analysis was developed using the forward selection method and criteria for obtaining the final model was $\mathrm{P}<0.05$. The data was analysed using the computerized statistical package SPSS, version 22.0 (SPSS Japan Inc., Tokyo. Japan), and a significance level of $5 \%$ was used. This study was approved by the ethical committee of Tokyo Dental College (Approval number 602).

\section{Results}

The frequency of having regular dental attendance by age and gender are shown in Figure 1. The distribution of regular dental attendance was $38.2 \%$. Among them, $47.8 \%$ were men and $52.2 \%$ were women. The frequency of having dental attendance was higher with increasing age among men. Meanwhile, in women, though the frequency of having regular dental attendance levelled off at the 40-49 year age range, the same trend in men was observed after the 50 year mark. The results of the chi-squared test in each age group show that although a significant difference was observed in the 30-39 year age range, there were no significant differences in the other age groups. 
Citation: Suzuki S, Yoshino S, Takayanagi A, Ishizuka Y, Satou R, et al. (2016) Factors associated with Regular Dental Attendance among White-collar Workers. Dentistry 6: 374. doi:10.4172/2161-1122.1000374

Page 3 of 5

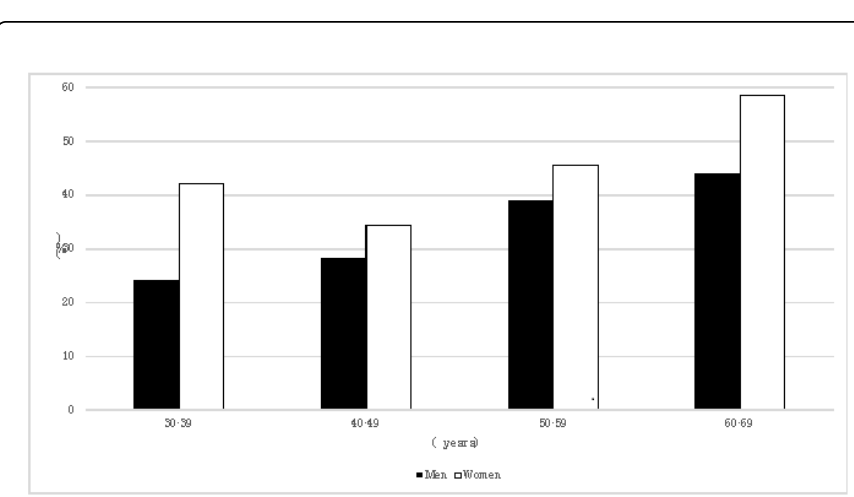

Figure 1: Frequency of having dental attendance by age and gender

\begin{tabular}{|c|c|c|c|c|c|}
\hline \multirow{2}{*}{\multicolumn{2}{|c|}{ Factors }} & \multicolumn{3}{|c|}{$\begin{array}{l}\text { Having regular } \\
\text { dental } \\
\text { attendance }\end{array}$} & \multirow{2}{*}{$\begin{array}{l}n \\
1023 \\
p \text {-value }\end{array}$} \\
\hline & & \multirow{2}{*}{$\begin{array}{l}n \\
561\end{array}$} & \multirow{2}{*}{$\begin{array}{l}\text { n } \\
187\end{array}$} & \multirow{2}{*}{$\begin{array}{l}\% \\
33\end{array}$} & \\
\hline \multirow[b]{2}{*}{ Gender } & Men & & & & \multirow[b]{2}{*}{$<0.001$} \\
\hline & Women & & 204 & 44 & \\
\hline \multirow[t]{2}{*}{ Age group (years) } & $30-49$ & 545 & 175 & 32 & \multirow[b]{2}{*}{$<0.001$} \\
\hline & $50-69$ & 478 & 216 & 45 & \\
\hline \multirow[b]{3}{*}{ Annual family income } & $\begin{array}{l}<4 \\
\text { yen }\end{array}$ & 277 & 85 & 31 & \multirow[b]{3}{*}{0.001} \\
\hline & $\begin{array}{l}4-6 \text { million } \\
\text { yen }\end{array}$ & 220 & 78 & 36 & \\
\hline & $\begin{array}{l}\geq 6 \quad \text { million } \\
\text { yen }\end{array}$ & 526 & 228 & 43 & \\
\hline \multicolumn{6}{|l|}{ Work environment } \\
\hline \multirow[b]{2}{*}{ Working hours } & $<8 \mathrm{~h}$ & 490 & 198 & 40 & \multirow[b]{2}{*}{0.021} \\
\hline & $\geq 8 \mathrm{~h}$ & 533 & 193 & 36 & \\
\hline \multirow[b]{2}{*}{ Shift work } & Yes & 189 & 56 & 30 & \multirow[b]{2}{*}{0.018} \\
\hline & No & 834 & 335 & 40 & \\
\hline \multicolumn{6}{|l|}{ Work stress } \\
\hline \multirow[b]{2}{*}{ My job is worth doing } & Yes & 637 & 270 & 42 & \multirow[b]{2}{*}{$<0.001$} \\
\hline & No & 386 & 121 & 31 & \\
\hline \multirow[b]{2}{*}{ I have to pay careful attention } & Yes & 604 & 220 & 36 & \multirow[b]{2}{*}{0.17} \\
\hline & No & 419 & 171 & 41 & \\
\hline \multirow[b]{2}{*}{ This job suits me well } & Yes & 719 & 296 & 41 & \multirow[b]{2}{*}{0.003} \\
\hline & No & 304 & 95 & 31 & \\
\hline \multirow{2}{*}{$\begin{array}{l}\text { The atmosphere at my workplace } \\
\text { is friendly }\end{array}$} & Yes & 814 & 321 & 39 & \multirow[b]{2}{*}{0.115} \\
\hline & No & 209 & 70 & 34 & \\
\hline \multirow[b]{2}{*}{ I feel stressed about my work } & Yes & 619 & 218 & 35 & \multirow[b]{2}{*}{0.014} \\
\hline & No & 404 & 173 & 43 & \\
\hline
\end{tabular}

\begin{tabular}{|c|c|c|c|c|c|}
\hline \multicolumn{6}{|l|}{ Lifestyle } \\
\hline \multirow[b]{2}{*}{ Smoking status } & Smokers & 223 & 68 & 31 & \multirow[b]{2}{*}{0.007} \\
\hline & $\begin{array}{l}\text { Non- } \\
\text { smokers or } \\
\text { ever } \\
\text { smokers }\end{array}$ & 800 & 323 & 40 & \\
\hline \multirow[b]{2}{*}{$\begin{array}{l}\text { Frequency of eating breakfast on } \\
\text { weekdays }\end{array}$} & Every day & 769 & 312 & 41 & \multirow[b]{2}{*}{0.007} \\
\hline & $\begin{array}{ll}\text { Not } & \text { every } \\
\text { day } & \end{array}$ & 254 & 79 & 31 & \\
\hline \multirow[b]{2}{*}{ Duration of eating breakfast } & $\begin{array}{l}\text { Not eating } \\
\text { breakfast } \\
\text { and <5 } \\
\text { minutes }\end{array}$ & 360 & 107 & 30 & \multirow[b]{2}{*}{$<0.001$} \\
\hline & $\geq 5$ minutes & 663 & 284 & 43 & \\
\hline \multirow[b]{2}{*}{$\begin{array}{l}\text { Frequency of eating dinner on } \\
\text { weekdays }\end{array}$} & Every day & 920 & 354 & 39 & \multirow[b]{2}{*}{0.669} \\
\hline & $\begin{array}{l}\text { Not every } \\
\text { day }\end{array}$ & 103 & 37 & 36 & \\
\hline \multirow{2}{*}{$\begin{array}{l}\text { Frequency of eating out on } \\
\text { weekdays }\end{array}$} & $\begin{array}{l}\text { More than } \\
1 \text { time per } \\
\text { week }\end{array}$ & 690 & 267 & 39 & \multirow[b]{2}{*}{0.653} \\
\hline & Never & 333 & 124 & 37 & \\
\hline \multirow[b]{2}{*}{ Eating snacks between meals } & Yes & 803 & 312 & 39 & \multirow[b]{2}{*}{0.551} \\
\hline & No & 205 & 75 & 37 & \\
\hline \multicolumn{6}{|l|}{ Oral hygiene behaviour } \\
\hline \multirow[b]{2}{*}{ Frequency of daily brushing } & $<2$ & 205 & 57 & 28 & \multirow[b]{2}{*}{0.001} \\
\hline & $\geq 2$ & 818 & 334 & 41 & \\
\hline \multirow[b]{2}{*}{ Duration of brushing teeth } & $<3$ minutes & 545 & 235 & 43 & \multirow[b]{2}{*}{0.001} \\
\hline & $\geq 3$ minutes & 478 & 156 & 33 & \\
\hline \multicolumn{6}{|l|}{ Timing of brushing teeth } \\
\hline \multirow[b]{2}{*}{ After eating breakfast } & Yes & 679 & 273 & 40 & \multirow[b]{2}{*}{0.066} \\
\hline & No & 344 & 118 & 34 & \\
\hline \multirow[b]{2}{*}{ After eating lunch } & Yes & 334 & 144 & 43 & \multirow[b]{2}{*}{0.025} \\
\hline & No & 689 & 247 & 36 & \\
\hline \multirow[b]{2}{*}{ Before bed time } & Yes & 597 & 260 & 44 & \multirow[b]{2}{*}{0.001} \\
\hline & No & 426 & 131 & 31 & \\
\hline
\end{tabular}

Table 2: Factors associated with having dental attendance using a chisquared test

Table 2 shows the relationship between dental attendance and work environment, life style and oral hygiene behaviour. Significant differences in gender $(\mathrm{P}<0.001)$, age $(\mathrm{P}<0.001)$, family income $(\mathrm{P}<0.01)$, working hours $(\mathrm{P}<0.05)$, shift work $(\mathrm{P}<0.05)$, My job is worth doing $(\mathrm{P}<0.01)$, This job suits me well $(\mathrm{P}<0.01)$, I feel stressed about my work $(\mathrm{P}<0.05)$, smoking status $(\mathrm{P}<0.01)$, frequency of eating breakfast $(\mathrm{P}<0.01)$, duration of eating breakfast $(\mathrm{P}<0.001)$, frequency of daily brushing $(\mathrm{P}<0.01)$, duration of brushing teeth $(\mathrm{P}<0.01)$, 
brushing after lunch $(\mathrm{P}<0.05)$ and brushing before bed time $(\mathrm{P}<0.01)$ were observed.

The result of the multiple logistic regression analysis with having dental attendance as a dependent variable is presented in Table 3 . The independent variables were adjustment factors, work environment, lifestyle and oral hygiene behaviour. By using the forward selection method, eight factors were selected. The highest adjusted odds ratio (AOR) was observed for duration of eating breakfast (AOR, 1.72; 95\% CI, 1.285-2.297), brushing before bed time (AOR, 1.72; 95\% CI, 1.3022.263), duration of brushing teeth (AOR, 1.56; 95\% CI, 1.188-2.046), shift work (AOR, 1.55; 95\% CI, 1.067-2.261)and My job is worth doing (AOR, 1.50; 95\% CI, 1.129-1.993).

\begin{tabular}{|c|c|c|c|c|}
\hline & Factors & AOR & $95 \% \mathrm{Cl}$ & $\begin{array}{l}\mathrm{p}- \\
\text { value }\end{array}$ \\
\hline \multirow[b]{2}{*}{ Shift work } & Yes & 1 & & \\
\hline & No & 1.553 & $\begin{array}{l}1.067- \\
2.261\end{array}$ & 0.022 \\
\hline \multirow[b]{2}{*}{ My job is worth doing } & No & 1 & & \\
\hline & Yes & 1.5 & $\begin{array}{l}1.129- \\
1.993\end{array}$ & 0.005 \\
\hline \multirow{2}{*}{$\begin{array}{l}\text { Duration of eating } \\
\text { breakfast }\end{array}$} & $\begin{array}{l}\text { Not eating breakfast and }<5 \\
\text { minutes }\end{array}$ & 1 & & \\
\hline & $\geq 5$ minutes & 1.718 & $\begin{array}{l}1.285- \\
2.297\end{array}$ & $\begin{array}{l}<0.00 \\
1\end{array}$ \\
\hline \multirow{2}{*}{$\begin{array}{l}\text { Duration of brushing } \\
\text { teeth }\end{array}$} & $<3$ minutes & 1 & & \\
\hline & $\geq 3$ minutes & 1.559 & $\begin{array}{l}1.188- \\
2.046\end{array}$ & 0.001 \\
\hline \multirow{2}{*}{$\begin{array}{l}\text { Brushing before bed } \\
\text { time }\end{array}$} & No & 1 & & \\
\hline & Yes & 1.717 & $\begin{array}{l}1.302- \\
2.263\end{array}$ & $\begin{array}{l}<0.00 \\
1\end{array}$ \\
\hline
\end{tabular}

Table 3: Factors associated with having regular dental attendance using multiple logistic regression

\section{Discussion}

We revealed that work environment, lifestyle and oral hygiene behaviour were associated with having regular dental attendance even after adjusting for possible confounding factors among white-collar workers. Initially, the result of a chi-squared test for revealing factors associated with having regular dental attendance showed that work environment, lifestyle and oral hygiene behaviour were related to dental attendance. Subsequently, the result of the multiple logistic regression analysis suggests that shift work, factors associated with work stress, duration of eating breakfast, duration of brushing teeth and brushing before bedtime were associated with dental attendance.

Although there have been few studies on a relationship between shift work and dental diseases, a relationship between shift work and systemic diseases such as cancer, cardiovascular disease and gastrointestinal disease have been discussed [22,23]. Knutsson reported that the possibility of affecting shift work on behavioural changes and stress because of shift work could cause disturbed sociotemporal patterns [24]. Thus, the present study suggests that behavioural changes affected by shift work could prevent regular dental attendance.

With regard to a relationship between work stress and dental diseases, Marcenes et al. showed that among 164 male workers from 35 to 44 years of age, work-related mental demand was tied to periodontal diseases [15]. Few reports are available in terms of work stress and regular dental attendance. The result of our study showed that work stress could prevent regular dental attendance. Chandola et al. found that in the process of revealing the mechanisms for work stress and coronary heart disease, work stress was associated with low physical activity [25]. Therefore, reducing work stress may promote regular dental attendance.

A relationship between the omission of breakfast and dental diseases has been reported in several studies $[16,18]$. Meanwhile, there have been several reports supporting the duration of eating breakfast and regular dental attendance. Therefore, it is unclear how the omission of breakfast affects regular dental attendance. However, Harada et al. reported in a cross-sectional study, which targeted 1182 dentate people over 18 years of age, that considering dietary combination carefully was associated with regular dental attendance [17]. They also suggested an association between healthier lifestyle and dental health behaviour. Thus, the result of the present study shows that a healthy lifestyle may result in regular dental attendance.

Some previous studies have discussed a relationship between oral hygiene behaviour and regular dental attendance. In terms of a relationship between the frequency of daily brushing and regular dental attendance, Sugihara et al. found that in a cross-sectional study targeting 211 people between 60 and 98 years of age, cleaning teeth or dentures three or more times per day was one of the associated factors for regular dental attendance [20]. Moreover, Hill et al. reported that there was an association between attendance patterns and frequency of tooth brushing [19]. However, there have been few studies about a relationship between the duration of brushing teeth and regular dental attendance. In the present study, although significant differences in frequency of tooth brushing and duration of brushing teeth were observed by a chi-squared (Table 2), only the duration of brushing teeth was significantly different (Table 3 ). We assumed that oral hygiene instructions associated with regular dental attendance or high awareness of oral hygiene led to a longer duration of brushing teeth.

However, the present study had several limitations. First, the answers for each question may have contained incorrect information as the study was a self-reported questionnaire. Second, the Internet survey can be a source of selection bias. Third, factors such as education, number of years of shift work and break time were not controlled. Moreover, we did not included whole items of the New Brief Job Stress Questionnaire as we considered that it may be overtasking for respondents to answer too many items. Therefore, these factors may be additional confounders. Forth, the sample population of our study was limited to only white collar workers in Japan. Therefore, it is unclear that this result can apply to other populations and this could be an additional selection bias. Finally, the present study was a cross-sectional study. Therefore, further research is required to demonstrate a causal relationship.

Despite these limitations, we revealed that among white-collar workers, work environment, lifestyle and oral hygiene behaviour were associated with regular dental attendance. In particular, shift work and work stress were associated with regular dental attendance with regard to work environment. Our findings suggest that health care providers 
might be able to promote dental attendance by informing workers that the work environment, lifestyle and oral hygiene behaviour might be associated with regular dental attendance.

\section{Acknowledgement}

This work was supported by the 'Research Fund of Clinical Study for Industrial Accident and Disease [grant number 14020101-02] from the Japanese Ministry of Health, Labour and Welfare.

\section{References}

1. Almoznino G, Aframian DJ, Sharav Y, Sheftel Y, et al. (2015) Lifestyle and dental attendance as predictors of oral health-related quality of life. Oral Dis 21: 659-666.

2. Donaldson AN, Everitt B, Newton T, Steele J, Sherriff M, et al. (2008) The effects of social class and dental attendance on oral health. J Dent Res 87: 60-64.

3. Petersen PE, Kjøller M, Christensen LB, Krustrup U (2004) Changing dentate status of adults, use of dental health services, and achievement of national dental health goals in Denmark by the year 2000. J Public Health Dent 64: 127-135.

4. Sugihara N, Maki Y, Matsukubo T, Takaesu Y (2005) Relation of Dental Visits by Japanese Elderly to Dental Characteristics and Oral Condition. Dentistry in Japan 41: 86-88.

5. Thomson WM, Williams SM, Broadbent JM, Poulton R, Locker D (2010) Long-term dental visiting patterns and adult oral health. J Dent Res 89: 307-311.

6. Ellershaw A (2014) Dental attendance patterns of Australian adults. Aust Dent J 59: 129-134.

7. Listl S (2011) Income-related inequalities in dental service utilization by Europeans aged 50+. J Dent Res 90: 717-723.

8. Manski RJ, Moeller JF, Chen H, St Clair PA, Schimmel J, et al. (2012) Wealth effect and dental care utilization in the United States. J Public Health Dent 72: 179-189.

9. Marino RJ, Khan AR, Tham R, Khew CW, Stevenson C (2014) Pattern and factors associated with utilization of dental services among older adults in rural Victoria. Aust Dent J 59: 504-510.

10. Ohi T, Sai M, Kikuchi M, Hattori Y, Tsuboi A, et al. (2009) Determinants of the utilization of dental services in a community-dwelling elderly Japanese population. Tohoku J Exp Med 218: 241-249.

11. Watt RG, Steele JG, Treasure ET, White DA, Pitts NB, et al. (2013) Adult Dental Health Survey 2009: implications of findings for clinical practice and oral health policy. Br Dent J 214: 71-75.
12. Tsutsumi A, Kayaba K, Yoshimura M, Sawada M, Ishikawa S, et al. (2003) Association between job characteristics and health behaviors in Japanese rural workers. Int J Behav Med 10: 125-142.

13. Suzuki S, Yoshino K, Takayanagi A, Ishizuka Y, Satou R, et al. (2015) Comparison of risk factors for tooth loss between professional drivers and white-collar workers: An internet survey. Industrial Health.

14. Ishizuka Y, Yoshino K, Takayanagi A, Sugihara N, Maki Y, et al. (2016) Comparison of the oral health problems and behavior of male daytimeonly and night-shift office workers: An Internet survey. J Occup Health.

15. Marcenes WS, Sheiham A (1992) The relationship between work stress and oral health status. Soc Sci Med 35: 1511-1520.

16. Bruno-Ambrosius K, Swanholm GT, wetman S (2005) Eating habits, smoking and toothbrushing in relation to dental caries: a 3-year study in Swedish female teenagers. International Journal of Paediatric Dentistry 15: 190-196.

17. Harada S, Akhter R, Kurita K, Mori M, Hoshikoshi M, et al. (2005) Relationships between lifestyle and dental health behaviors in a rural population in Japan. Community Dent Oral Epidemiol 33: 17-24.

18. Samnieng P, Ueno M, Zaitsu T, Shinada K, Wright FA, et al. (2013) The relationship between seven health practices and oral health status in community-dwelling elderly Thai. Gerodontology 30: 254-261.

19. Hill KB, Chadwick B, Freeman R, O'Sullivan I, Murray JJ (2013) Adult Dental Health Survey 2009: relationships between dental attendance patterns, oral health behaviour and the current barriers to dental care. $\mathrm{Br}$ Dent J 214: 25-32.

20. Sugihara N, Tsuchiya K, Hosaka M, Osawa H, Yamane GY, et al. (2010) Dental-care utilization patterns and factors associated with regular dental check-ups in elderly. Bulletin of Tokyo Dental College 51: 15-21.

21. The English version of the New Brief Job Stress Questionnaire (2016).

22. Knutsson A (2003) Health disorders of shift workers. Occup Med (Lond) 53: 103-108.

23. Wang XS, Armstrong ME, Cairns BJ, Key TJ, Travis RC (2011) Shift work and chronic disease: the epidemiological evidence. Occup Med (Lond) 61: 78-89.

24. Knutsson A (1989) Shift work and coronary heart disease. Scand J Soc Med Suppl 44: 1-36.

25. Chandola T, Britton A, Brunner E, Hemingway H, Malik M, et al. (2008) Work stress and coronary heart disease: what are the mechanisms? Eur Heart J 29: 640-648. 